\title{
Expression of Concern to: Comparison of outcomes in patients with methicillin- susceptible Staphylococcus aureus (MSSA) bacteremia who are treated with $\beta$-lactam vs vancomycin empiric therapy: a retrospective cohort study
}

\author{
Davie Wong
}

The Editor is issuing this Expression of Concern to alert readers to a number of issues with respect to this article (1).

The article [1] was published with the following list of authors: Davie Wong, Titus Wong, Marc Romney and Victor Leung. After publication, it came to the attention of the Editor that there is significant text overlap with [2], although both articles present different conclusions. A subsequent investigation has found that the first author, Davie Wong, performed additional research on an increased group of patients and submitted article [1] to BMC Infectious Diseases without the knowledge of the colleagues listed as co-authors, while another version of the article based on fewer patient records was under consideration in Annals of Clinical Microbiology and Antimicrobials and subsequently published as [2]. Davie Wong takes sole responsibility for the results presented in this article [1].

Article [1] presents a comparison of beta-lactams (including cloxacillin/cefazolin, ceftriaxone, piptazo,etc.) vs vancomycin, whereas article [2] is a comparison of cloxacillin/cefazolin vs vancomycin in the empiric treatment of MSSA bacteremia. This may explain the difference

The original article can be found online at https://doi.org/10.1186/s12879016-1564-5.

Correspondence: davie1985@hotmail.com

PGY-V Infectious Diseases Residency Training Program, University of British Columbia, Vancouver General Hospital, D 452 Heather Pavilion, 2733 Heather Street, Vancouver, BC V5Z 1 M9, Canada in the conclusions between articles (1) and (2). The institution where this research was carried out has been unable to confirm this. Therefore the Editor advises that readers interpret the data presented with caution.

In addition, the author wishes to clarify that in article [1] in the "Methods" section under "Patients" subsection, an additional sentence should be included: "The vancomycin group may or may not have been briefly exposed to $\beta$ lactam antibiotics during empiric therapy". This is to indicate exposure to $\beta$-lactam was permitted, whereas in article [2], the sentence "The vancomycin group was not exposed to any $\beta$-lactams until the start of definitive therapy" excludes patients who had any $\beta$-lactam exposure.

All authors agree to the publication of this Editorial Expression of Concern.

\section{Author's contributions}

The author(s) read and approved the final manuscript.

Published online: 05 August 2020

\section{References}

1. Wong $D$, Wong $T$, Romney $M$, Leung V. Comparison of outcomes in patients with methicillin-susceptible Staphylococcus aureus (MSSA) bacteremia who are treated with $\beta$-lactam vs vancomycin empiric therapy: a retrospective cohort study. BMC Infect Dis. 2016;16:224.

2. Wong $D$, Wong $T$, Romney $M$, Leung V. Comparative effectiveness of $\beta$ lactam versus vancomycin empiric therapy in patients with methicillinsusceptible Staphylococcus aureus (MSSA) bacteremia. Ann Clin Microbiol Antimicrob. 2016;15:27.

(c) The Author(s). 2020 Open Access This article is licensed under a Creative Commons Attribution 4.0 International License, which permits use, sharing, adaptation, distribution and reproduction in any medium or format, as long as you give appropriate credit to the original author(s) and the source, provide a link to the Creative Commons licence, and indicate if changes were made. The images or other third party material in this article are included in the article's Creative Commons licence, unless indicated otherwise in a credit line to the material. If material is not included in the article's Creative Commons licence and your intended use is not permitted by statutory regulation or exceeds the permitted use, you will need to obtain permission directly from the copyright holder. To view a copy of this licence, visit http://creativecommons.org/licenses/by/4.0/ The Creative Commons Public Domain Dedication waiver (http://creativecommons.org/publicdomain/zero/1.0/) applies to the data made available in this article, unless otherwise stated in a credit line to the data. 